\title{
Lactococcus lactis is capable of improving the riboflavin status in deficient rats
}

\author{
Jean Guy LeBlanc ${ }^{1 *}$, Catherine Burgess ${ }^{2}$, Fernando Sesma ${ }^{1}$, Graciela Savoy de Giori ${ }^{1,3}$ \\ and Douwe van Sinderen ${ }^{2,4}$ \\ ${ }^{1}$ Centro de Referencia para Lactobacilos (CERELA-CONICET), Chacabuco 145, Tucumán, T4000ILC, Argentina \\ ${ }^{2}$ Department of Microbiology and Biosciences Institute, National University of Ireland Cork, Western Road, Cork, Republic of Ireland \\ ${ }^{3}$ Cátedra de Microbiología Superior, Universidad Nacional de Tucumán (UNT), Tucumán, T4000ILC, Argentina \\ ${ }^{4}$ Alimentary Pharmabiotic Centre, Biosciences Institute, National University of Ireland Cork, Western Road, Cork, Republic of Ireland
}

(Received 4 October 2004 - Revised 11 February 2005 - Accepted 22 February 2005)

\begin{abstract}
Lactococcus lactis is a commonly used starter strain that can be converted from a vitamin $\mathrm{B}_{2}$ consumer into a vitamin $\mathrm{B}_{2}$ 'factory' by over-expressing its riboflavin biosynthesis genes. The present study was conducted to assess in a rat bioassay the response of riboflavin produced by GM or native lactic acid bacteria (LAB). The riboflavin-producing strains were able to eliminate most physiological manifestations of ariboflavinosis such as stunted growth, elevated erythrocyte glutathione reductase activation coefficient values and hepatomegalia that were observed using a riboflavin depletion-repletion model. Riboflavin status and growth rates were greatly improved when the depleted rats were fed with cultures of $L$. lactis that overproduced this vitamin whereas the native strain did not show the same effect. The present study is the first animal trial with food containing living bacteria that were engineered to overproduce riboflavin. These results pave the way for analysing the effect of similar riboflavin-overproducing LAB in human trials.
\end{abstract}

Riboflavin: Lactic acid bacteria: Ariboflavinosis: Genetically modified micro-organisms

Riboflavin (vitamin $\mathrm{B}_{2}$ ) is a water-soluble vitamin belonging to the B-complex group that is important for optimal body growth and erythrocyte production and helps in releasing energy from carbohydrates. In the body, riboflavin is primarily found as an integral component of the coenzymes FAD and FMN. These flavin-containing coenzymes participate in redox reactions in numerous metabolic pathways such as the metabolism of carbohydrates, fats and proteins. They are also involved in the metabolism of folate, vitamin $\mathrm{B}_{12}$, vitamin $\mathrm{B}_{6}$, and other vitamins, which explains why plasma riboflavin is a determinant of plasma homocysteine, which is associated with CVD, pregnancy complications, and cognitive impairment (Hustad et al. 2000, 2002).

Although riboflavin is found in a wide variety of foods (dairy products, lean meats, poultry, fish, grains, broccoli, turnip greens, asparagus, spinach and enriched food products), vitamin $\mathrm{B}_{2}$ deficiency is common in many parts of the world, particularly in developing countries (Boisvert et al. 1993). Several studies have indicated that vitamin $B_{2}$ deficiency may be widespread in industrialised countries as well, both in the elderly (Bailey et al. 1997; Madigan et al. 1998) and in young adults (Benton et al. 1997).

Vitamin $B_{2}$ status in human subjects has usually been assessed by measuring the erythrocyte glutathione reductase activation coefficient (EGRAC), which is the ratio between enzyme activity determined with and without the addition of the cofactor FAD (Glatzle et al. 1970). Glutathione reductase loses FAD at an early stage in vitamin $\mathrm{B}_{2}$ deficiency, making the EGRAC a useful method for the diagnosis of vitamin $\mathrm{B}_{2}$ deficiency (Bates, 1993).

Riboflavin-deficient rat models have been utilised for a number of years to study the biological effects of riboflavin. Using these models, it has been shown that riboflavin: (i) is important in the early postnatal development of the brain (Ogunleye \& Odutuga, 1989) and gastrointestinal tract (Williams et al. 1995, 1996; Yates et al. 2001, 2003); (ii) is able to modulate carcinogeninduced DNA damage (Pangrekar et al. 1993; Webster et al. 1996); (iii) plays a role in $\mathrm{Fe}$ absorption and utilisation (Powers, 1987; Powers et al. 1988, 1991, 1993; Butler \& Topham, 1993); (iv) can modulate inflammatory responses (Lakshmi et al. 1991). These models also allow the extrapolation of data obtained in an animal model to human clinical data (Greene et al. 1990).

Previously, we described the genetic analysis of the riboflavin biosynthetic (rib) operon in the lactic acid bacterium Lactococcus lactis ssp. cremoris strain NZ9000 (Burgess et al. 2004). This strain can be converted from a vitamin $\mathrm{B}_{2}$ consumer into a vita$\min B_{2}$ 'factory' by over-expressing its riboflavin biosynthesis genes. Substantial riboflavin overproduction is seen in the growth medium when all four biosynthetic genes (ribG, ribH, $r i b B$ and $r i b A$ ) are over-expressed simultaneously (in L. lactis NZ9000 containing pNZGBAH). Also, spontaneous mutants (i.e. L. lactis strain $\mathrm{CB} 010$ ) capable of producing riboflavin in the growth medium, although at a lower level than the engineered 
strain, were identified. Such spontaneously riboflavin-overproducing strains have a considerable advantage over the genetically engineered strain as they can be promptly implemented in industrial fermentation.

The main objective of the present study was to evaluate the bioavailability of riboflavin from spontaneous and engineered riboflavin-overproducing $L$. lactis strains using a depletionrepletion rat bioassay. These strains could be used in the development of novel fermented foods containing increased levels of riboflavin, produced in situ, which eliminates the need for vitamin fortification.

\section{Materials and methods}

Bacterial strains, media and culture conditions

L. lactis strains NZ9000 (L. lactis $\mathrm{B}_{2}-$ ) and CB010 (L. lactis $\mathrm{B}_{2}+$ ) were grown $\left(12 \mathrm{~h}\right.$ at $\left.30^{\circ} \mathrm{C}\right)$ in $\mathrm{M} 17$ medium (Biokar Diagnostics, Beauvais, France) supplemented with $0.5 \%$ glucose (M17-Glu). L. lactis NZ9000 harbouring plasmid pNZGBAH (L. lactis $\mathrm{B}_{2}++$ ) (Burgess et al. 2004) were grown at $30^{\circ} \mathrm{C}$ in M17-Glu supplemented with chloramphenicol $(5 \mu \mathrm{g} / \mathrm{ml})$. Nisin was added $(1 \mathrm{ng} / \mathrm{ml})$ after $4 \mathrm{~h}$ growth when required.

\section{Quantitative analysis of riboflavin in culture medium}

Extracellular riboflavin concentrations of L. lactis cultures were measured by reverse-phase HPLC using a modification of a previously described technique (Capo-Chichi et al. 2000). Briefly, proteins from a cell-free supernatant fraction were precipitated from a $1 \mathrm{ml}$ sample by adding $10 \%$ TCA. HPLC analysis (Isco model 2360; Teledyne Isco Inc., Lincoln, NE, USA) of the resulting liquid was performed using a $\mathrm{C} 18$ reverse-phase column $(4 \times 150 \mathrm{~mm}$; Varian, Inc., Palo Alto, CA, USA $)$ with a linear gradient of acetonitrile from $3.6 \%$ to $30 \%$ at pH 3.2 (HPLCgrade water containing $0.1 \%$ acetic acid). Fluorescent detection was used and the excitation and emission wavelengths were 445 and $530 \mathrm{~nm}$, respectively. Commercially obtained riboflavin, FMN and FAD were used as references and to obtain a standard curve (Sigma, Buenos Aires, Argentina).

\section{Experimental design}

The overall experimental protocol is summarised in Fig. 1. Ninety weanling specific pathogen-free conventional Wistar rats (weighing $60 \pm 3 \mathrm{~g}$ ) were obtained from the inbred colony maintained $\left(12 \mathrm{~h}\right.$ light cycle; $\left.22 \pm 2^{\circ} \mathrm{C}\right)$ in the Nutrition Department of the Universidad Nacional de Tucumán (Argentina). Rats were individually housed in wire-based cages (to prevent coprophagy) and were allowed free access to a riboflavin-deficient diet (ICN Biomedicals Inc., Irvine, CA, USA) and water throughout the study.

The rats were weight matched into three main groups of animals. The first group was a depleted group where animals were fed the riboflavin-deficient diet during $42 \mathrm{~d}$. The second group was a non-depleted group where animals received the riboflavin-deficient diet supplemented with commercial riboflavin (15 mg B $\mathrm{B}_{2} / \mathrm{kg}$; Sigma, Buenos Aires, Argentina) during $42 \mathrm{~d}$. The third group was a depleted-replete group where rats were fed the riboflavin-deficient diet for $21 \mathrm{~d}$ (depletion period) followed by a $21 \mathrm{~d}$ repletion period where animals were fed the same diet supplemented with (i) different levels of commercial

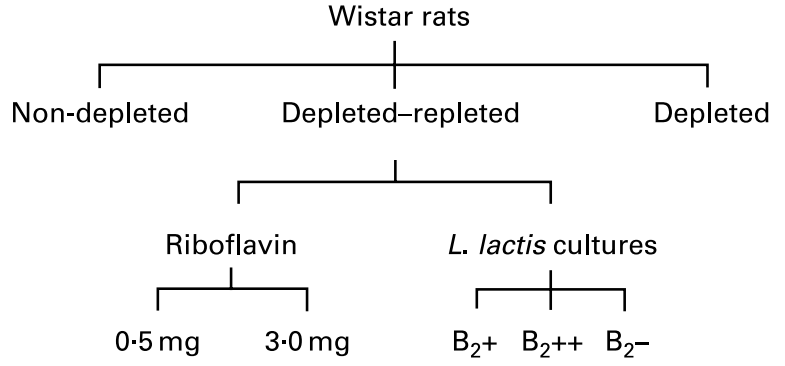

Fig. 1. Riboflavin depletion-repletion experimental protocol. The depleted group were fed a riboflavin-deficient diet (RDD) during $42 \mathrm{~d}$; the non-depleted group received the RDD supplemented with commercial riboflavin during $42 \mathrm{~d}$; the depleted-replete group were fed the RDD for $21 \mathrm{~d}$ (depletion period) followed by a $21 \mathrm{~d}$ repletion period where animals were fed the same diet supplemented with (i) different levels of commercial riboflavin, or (ii) wild-type or engineered riboflavin-producing lactic acid bacteria (Lactococcus lactis $\mathrm{B}_{2}+$ and $L$. lactis $\mathrm{B}_{2}++$, respectively) or the control strain (L. lactis $\mathrm{B}_{2}-$ ).

riboflavin, or (ii) wild-type or engineered riboflavin-producing lactic acid bacteria (LAB; L. lactis $\mathrm{B}_{2}+$ and L. lactis $\mathrm{B}_{2}++$, respectively) or (iii) the control strain (L. lactis $\mathrm{B}_{2}-$ ), which were grown in M17-Glu. Commercial riboflavin was added at concentrations equivalent to: (i) the residual riboflavin found in $\mathrm{B}_{2}$-free diets used in previous deficiency studies $\left(0.5 \mathrm{mg} \mathrm{B}_{2} / \mathrm{kg}\right.$ diet; Powers et al. 1991, 1993; Yates et al. 2001, 2003); (ii) the daily riboflavin requirement of laboratory rats $\left(3.0 \mathrm{mg} \mathrm{B}_{2} / \mathrm{kg}\right.$ diet; Institute for Laboratory Animal Research, 1995). In the second depleted-replete group, rats were fed $20 \mathrm{ml}$ LAB-containing M17-Glu broth twice daily during the repletion period in replacement of their drinking water, which contained 0.0 (SD 0.1), 0.5 (SD 0.2) or 15.0 (SD 5) $\mathrm{mg} / \mathrm{l}$ for L. lactis $\mathrm{B}_{2}-$, $\mathrm{B}_{2}+$ and $\mathrm{B}_{2}++$, respectively (determined by HPLC). Animal live weight and food intake (given ad libitum) were determined on a bi-daily basis. Growth rates were calculated during the repletion period ( $21 \mathrm{~d})$ using the mean average bi-daily increase and were expressed as changes in live animal weight $(\mathrm{g})$ per $\mathrm{d}$.

\section{Blood and organ collection}

Throughout the trial, rats from each group were placed into a homemade sampling chamber, and whole blood was collected from the tail and transferred into a tube containing anticoagulant for EGRAC evaluation (see p. 262). At the end of the trial, animals were anaesthetised with an intraperitoneal injection of ketamin $(10 \%)$-xylacin $(2 \%)(3.0 \mathrm{ml} / \mathrm{kg}$ animal weight; $40: 60, \mathrm{v} / \mathrm{v}$; Alfasan, Woerden, The Netherlands) and bled by cardiac puncture. Blood was transferred into tubes containing anticoagulant (heparin; Rivero, Buenos Aires, Argentina) and centrifuged (2000 $g$ for $15 \mathrm{~min}$ at $4^{\circ} \mathrm{C}$ ). Plasma was removed and stored at $-70^{\circ} \mathrm{C}$ until analysis. The sedimented cells were washed three times with cold $0 \cdot 15 \mathrm{M}-\mathrm{NaCl}$. Erythrocytes $(0.5 \mathrm{ml})$ were haemolysed by adding distilled water $(9.5 \mathrm{ml})$ and stored at $-70^{\circ} \mathrm{C}$ for EGRAC determinations. Freshly excised organs (liver, spleen and kidneys) were rinsed with $0 \cdot 15 \mathrm{M}-\mathrm{NaCl}$, weighed and stored at $-70^{\circ} \mathrm{C}$.

\section{Riboflavin status}

Riboflavin status was assessed by measuring the EGRAC using a modification of a previously described technique (Adelekan \& Thurnham, 1986). Briefly, haemolysed blood was allowed to 
thaw at room temperature under conditions of reduced light. Haemolysates $(31.3 \mu \mathrm{l})$ were added to $1 \mathrm{ml}$ potassium phosphate buffer (0.1 M; pH 7.4) containing 2.3 mM-ethylenediaminetetraacetic acid (dipotassium salt) and $0.89 \mathrm{~mm}-\mathrm{GSSG}$ with or without $8 \mu \mathrm{M}-\mathrm{FAD}$. The mixture was pre-incubated for $30 \mathrm{~min}$ at $37^{\circ} \mathrm{C}$ followed by the addition of $80 \mu \mathrm{M}-\mathrm{NADPH}$ to initiate the reaction. The absorbance at $340 \mathrm{~nm}$ was measured every $10 \mathrm{~min}$ during $1 \mathrm{~h}$ at $37^{\circ} \mathrm{C}$. Riboflavin status was calculated as the ratio (activity coefficient) of the rate of change of absorbance per time unit in the presence or absence of FAD. EGRAC were measured in triplicate for each sample.

\section{Statistics}

Comparisons were performed using the software package SigmaStat (SPSS Inc., Chicago, IL, USA). Comparisons of multiple means were accomplished by one-way ANOVA followed by Tukey's post hoc test and $P<0.05$ was considered significant. Unless otherwise indicated, all values are the means of three independent trials and standard deviations (where $n 30$ ).

\section{Results and discussion}

In order to study the bioavailability of riboflavin from native and engineered L. lactis strains, a depletion-repletion rat bioassay was used. Conventional Wistar rats were fed a riboflavin-deficient diet and their riboflavin status was followed using growth rate and EGRAC as indicators. The bioavailability of the riboflavin produced by the bacterial strains was compared with that of pure riboflavin given to rats at levels previously considered negligible $\left(0.5 \mathrm{mg} / \mathrm{B}_{2} \mathrm{~kg}\right.$ diet $)$ or at the daily recommended intake for such animals $\left(3.0 \mathrm{mg} \mathrm{B} \mathrm{B}_{2} / \mathrm{kg}\right.$ diet; for details, see p. 262).

\section{Animal growth during the depletion-repletion periods}

It is well documented that rats, which are deprived of riboflavin, exhibit an impairment of growth (Glatzle et al. 1968). Animal growth was followed throughout the trials. At the end of the depletion and repletion periods, a significant decrease was observed in the growth rate and final weight of the riboflavindepleted rats as compared with the non-depleted group (Table 1).
The animals supplemented with L. lactis $\mathrm{B}_{2}-$ showed significantly lower growth rates $(2.78(\mathrm{SD} 0.17) \mathrm{g} / \mathrm{d})$ as compared with those fed L. lactis $\mathrm{B}_{2}+$ or $0.5 \mathrm{mg} \mathrm{B} / \mathrm{kg}$ (3.30 (SD 0.20) and 3.19 (SD 0.16) $\mathrm{g} / \mathrm{d}$ respectively), suggesting that the riboflavin produced by the latter strains can exert a biological function. The L. lactis $\mathrm{B}_{2}-$ rats showed higher growth rates than the depleted animals, which only received the riboflavin-deficient diet $(0.68$ (SD 0.04) g/d). This last difference could be due to other residual nutrients found in the M17 broth after bacterial growth besides riboflavin since this vitamin was not detected after growth of L. lactis $\mathrm{B}_{2}-$ (HPLC determination). Interestingly, the animals that received $L$. lactis $\mathrm{B}_{2}+$ showed statistically similar growth rates as the group that received $0.5 \mathrm{mg} \mathrm{B} / 2 \mathrm{~kg}$, suggesting that the riboflavin produced by this bacterial strain, given here at the same concentration as the commercially available pure riboflavin, possesses similar bioavailability. The animals that received $L$. lactis $\mathrm{B}_{2}++$ showed a significantly higher growth rate (4.41 (SD 0.26) g/d) and final weight (224.0 (SD 13.4) g) than all the other depleted-replete groups (Table 1), an expected result since the riboflavin concentration of this culture (15.0 (SD 5) $\mathrm{mg} / \mathrm{l}$ ) was the highest used in the depleted-replete animals. The food consumption during the depletion and repletion periods did not differ significantly between the different experimental groups (data not shown).

\section{Riboflavin status (erythrocyte glutathione reductase activation coefficient)}

Activation assays such as the EGRAC are functional tests that show a decline in a specific enzyme activity as a result of riboflavin deficiency and a disproportionate increase in activity after the in vitro addition of this vitamin (Adelekan \& Thurnham, 1986). The rate of change of the assay is proportional to the amount of enzyme present. EGRAC values of 1.30 to 1.40 or higher are indicative of biochemical riboflavin deficiency. Riboflavin status, expressed in terms of the activation coefficient for the FAD-dependent enzyme erythrocyte glutathione reductase (EC 1.6.4.2), was determined throughout the study.

In order to show that EGRAC values correlate with the riboflavin status of rats, a validation test was performed where the EGRAC was followed at a weekly basis in animals fed with the

Table 1. Growth rate and live weight of animals fed a riboflavin-deficient diet during $21 \mathrm{~d}$ (depletion period), after which they received the same diet supplemented with commercial riboflavin or Lactococcus lactis strains (NZ9000 $\left(\mathrm{B}_{2}-\right)$, CB010 $\left(\mathrm{B}_{2}+\right)$, or NZ9000 (pNZGBAH) $\left.\left(\mathrm{B}_{2}++\right)\right)$ during $21 \mathrm{~d}$ (repletion period)

(Mean values and standard deviations)

\begin{tabular}{|c|c|c|c|c|c|c|c|c|}
\hline \multirow[b]{3}{*}{ Group* } & \multicolumn{4}{|c|}{ Depletion period } & \multicolumn{4}{|c|}{ Repletion period } \\
\hline & \multicolumn{2}{|c|}{ Growth rate $(g / d)$} & \multicolumn{2}{|c|}{ Final weight (g) } & \multicolumn{2}{|c|}{ Growth rate $(g / d)$} & \multicolumn{2}{|c|}{ Final weight $(\mathrm{g})$} \\
\hline & Mean & SD & Mean & SD & Mean & SD & Mean & SD \\
\hline Non-depleted & $5 \cdot 81^{a}$ & 0.35 & $138 \cdot 0^{\mathrm{a}}$ & $8 \cdot 3$ & $5 \cdot 34^{a}$ & 0.32 & $299 \cdot 2^{a}$ & $18 \cdot 0$ \\
\hline Depleted & $4.08^{b}$ & 0.24 & $102 \cdot 2^{\mathrm{b}}$ & $6 \cdot 1$ & $0.68^{b}$ & 0.04 & $141 \cdot 1^{b}$ & 8.5 \\
\hline L. lactis $\left(\mathrm{B}_{2}-\right)$ & & & & & $2 \cdot 78^{f}$ & 0.17 & $188 \cdot 9^{c}$ & $11 \cdot 3$ \\
\hline $\mathrm{B}_{2}(0.5 \mathrm{mg})$ & & & & & $3 \cdot 19^{c}$ & 0.16 & $190 \cdot 0^{c}$ & 9.5 \\
\hline $\mathrm{B}_{2}(3.0 \mathrm{mg})$ & & & & & $3 \cdot 61^{d}$ & 0.22 & $204 \cdot 2^{\mathrm{c}, \mathrm{d}}$ & $12 \cdot 5$ \\
\hline L. lactis $\left(\mathrm{B}_{2}++\right)$ & & & & & $4.41^{\mathrm{e}}$ & 0.26 & $224.0^{\mathrm{e}}$ & $13 \cdot 4$ \\
\hline L. lactis $\left(\mathrm{B}_{2}+\right)$ & & & & & $3 \cdot 30^{c}$ & 0.20 & $200 \cdot 0^{c, d}$ & $12 \cdot 0$ \\
\hline
\end{tabular}


riboflavin-deficient diet (depleted group). A significant increase in EGRAC values can be observed in the depleted group as compared with the non-depleted groups (Fig. 2). After only $7 \mathrm{~d}$, a significant increase in the EGRAC is seen in the depleted group (1.62 (SD 0.09)) and this value continues to increase in function of time (2.02 (SD 0.07) and 2.41 (SD 0.06) after 21 and $42 \mathrm{~d}$, respectively). In the non-depleted group, EGRAC values did not vary significantly $(1 \cdot 18-1 \cdot 29)$ showing that their riboflavin status remained normal throughout the study.

In order to determine if native and engineered LAB could improve the riboflavin status of deficient rats, cultures grown in M17-Glu were used to supplement the riboflavin-deficient diet for $21 \mathrm{~d}$ (repletion period) of previously depleted animals. HPLC analysis showed significant levels of riboflavin in the M17-Glu medium following growth of L. lactis $\mathrm{B}_{2}+$ or $\mathrm{B}_{2}++(0.5(\mathrm{SD} 0 \cdot 2)$ and 15 (SD 5) $\mathrm{mg} / \mathrm{l}$ respectively). This vitamin was below the detection level in the medium after growth of the non-producing strain (L. lactis $\mathrm{B}_{2}-$ ).

As was the case in the validation test, the depleted rats showed increased EGRAC values (2.41 (SD 0.06)) compared with the nondepleted animals (1.18 (SD 0.04)) after the repletion period (Fig. 3). The rats whose diet was supplemented with the non-producing strain (L. lactis $\mathrm{B}_{2}-$ ) showed statistically similar EGRAC values as those found in the depleted animals (2.35 (SD 0.06)). This result confirms that the increase in growth observed in the animals supplemented with the non-producing strains is not caused by riboflavin but by other residual nutrients found in the cultures broth. The rats whose diet was supplemented with either of the two riboflavin producing strains (L. lactis $\mathrm{B}_{2}+$ and $\mathrm{B}_{2}++$ ) exhibited significantly lower EGRAC values (1.65 (SD 0.09) and 1.31 (SD 0.05), respectively) as compared with rats of the depleted group (2.41 (SD 0.06)) or rats whose diet was supplemented with the non-producing strain (L. lactis $\mathrm{B}_{2}-$ ) (2.10 (SD 0.06)) (Fig. 3). Interestingly, the animals that received L. lactis $\mathrm{B}_{2}+$ showed statistically similar EGRAC values as the group that received $0.5 \mathrm{mg} \mathrm{B}_{2} / \mathrm{kg}$, suggesting that the riboflavin produced by this bacterial strain, given here at the same concentration as the commercially available pure riboflavin, possesses similar bioavailability, confirming the results seen in growth (Table 1).

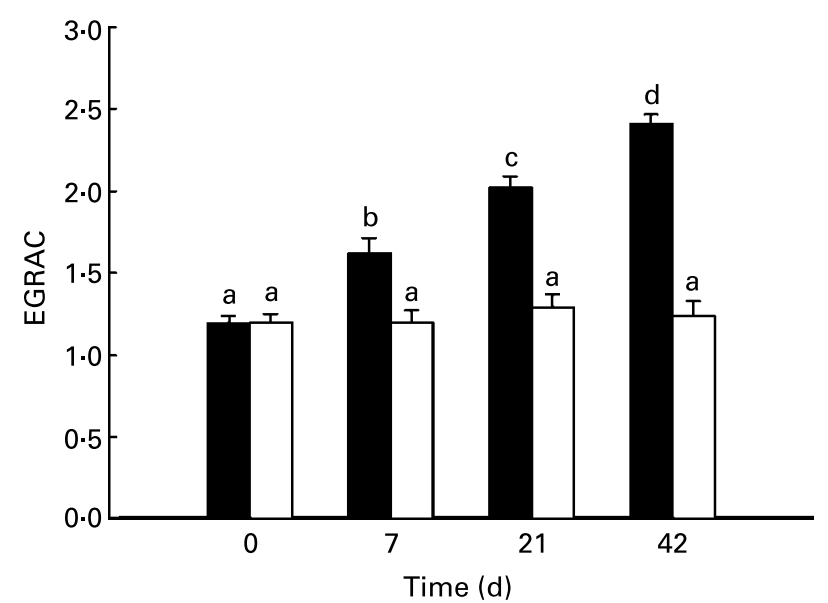

Fig. 2. Erythrocyte glutathione reductase activation coefficient (EGRAC) values of rats fed a riboflavin-deficient diet $(\mathbf{\square})$ or the same diet supplemented with commercial riboflavin $(15 \mathrm{mg} / \mathrm{kg} ; \square)$. Values are means, with standard deviations represented by vertical bars $(n 10)$. a,b,c,d Mean values with unlike letters are significantly different $(P<0.05)$.

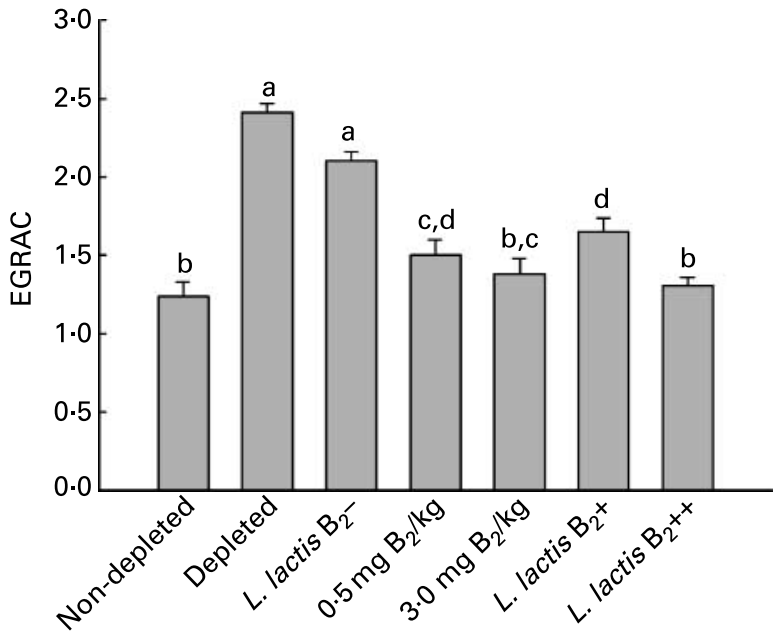

Fig. 3. Erythrocyte glutathione reductase activation coefficient (EGRAC) values of rats fed a riboflavin-deficient diet during $21 \mathrm{~d}$ followed by a $21 \mathrm{~d}$ repletion period where the diet was supplemented with different amounts of riboflavin $(0,0.5$ or $3.0 \mathrm{mg} / \mathrm{kg}$ diet $)$ or with cultures of Lactococcus lactis (NZ9000 $\left(B_{2}-\right)$, CB010 $\left(B_{2}+\right)$, or NZ9000 (pNZGBAH) $\left.\left(B_{2}++\right)\right)$. Values are means, with standard deviations represented by vertical bars $(n 10)$. a,b,c,d Mean values with unlike letters are significantly different $(P<0.05)$.

The animals that received $L$. lactis $\mathrm{B}_{2}++$ showed the lowest EGRAC values and, as was the case with the growth rates, this result was not surprising since the riboflavin concentration of this culture was the highest used in the depleted-replete animals. Surprisingly, no statistically significant differences in EGRAC values were observed between the animals that received $0.5 \mathrm{mg}$ $\mathrm{B}_{2} / \mathrm{kg}$ and those receiving $3.0 \mathrm{mg} \mathrm{B}_{2} / \mathrm{kg}$ (however, absolute values were lower in the $3.0 \mathrm{mg} \mathrm{B}_{2} / \mathrm{kg}$ group compared with the $0.5 \mathrm{mg} \mathrm{B} / 2$ group); a longer repletion period in future studies could improve the sensibility of the experiment.

\section{Organ weight comparison}

Another physiological effect of ariboflavinosis is hepatomegaly, which is the enlargement of the liver beyond its normal size. This problem is normally found in rats deficient in riboflavin (Glatzle et al. 1968).

An increase in the weight of the liver in relation to body weight was observed in the depletion groups where riboflavin deficiency was observed (Fig. 4).

The groups supplemented with $L$. lactis $\mathrm{B}_{2}-$ showed a significant increase in relative liver weight (5.4 (SD 0.5) g) as compared with the non-depleted group (4.4 (SD 0.2) g) and were statistically similar to the depletion groups (5.2 (SD 0.4) g) and the group that received $0.5 \mathrm{mg} \mathrm{B}_{2} / \mathrm{kg}(5.3$ (SD 0.5$) \mathrm{g}$ ). The groups supplemented with $L$. lactis $\mathrm{B}_{2}+$ or L. lactis $\mathrm{B}_{2}++$ showed no significant differences in relative liver weight compared with the nondepleted group or the group that received $3.0 \mathrm{mg} \mathrm{B} / \mathrm{kg}$. These results suggest that the riboflavin-producing strains are able to decrease the relative liver weight increases observed in the depleted animals. However, it is not possible to assess bioavailability of the riboflavin produced by the bacterial strains with these results since no significant differences were observed in the animals fed with either the producing strain $\left(\mathrm{B}_{2}+\right)$ or the overproducing strain $\left(\mathrm{B}_{2}++\right)$, which have very important 


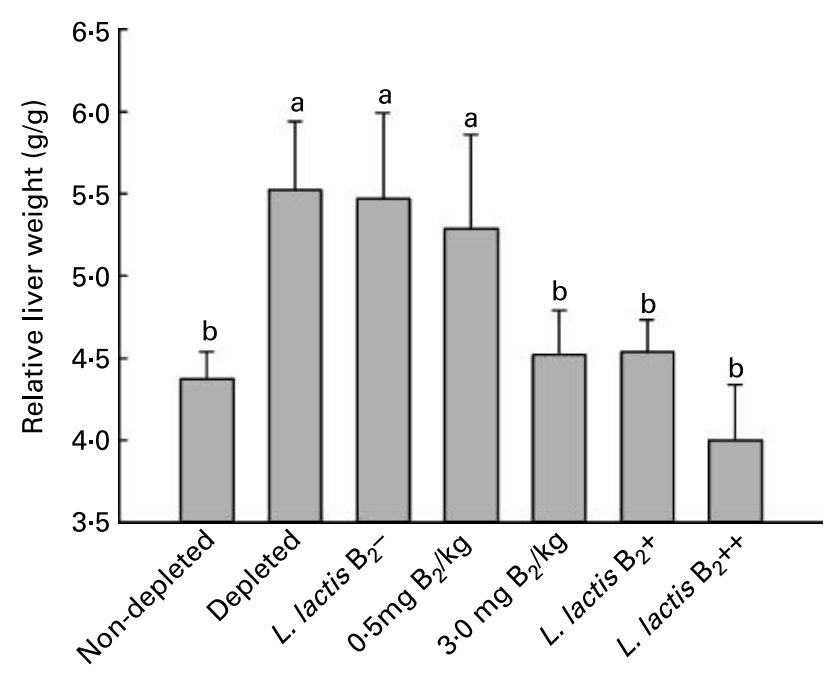

Fig. 4. Relative weight of liver of animals fed a riboflavin-deficient diet during $21 \mathrm{~d}$ followed by a $21 \mathrm{~d}$ repletion period where the diet was supplemented with different amounts of riboflavin $(0,0.5$ or $3.0 \mathrm{mg} / \mathrm{kg}$ diet) or with cultures of Lactococcus lactis (NZ9000 $\left(\mathrm{B}_{2}-\right)$, $\quad$ CB010 $\left(\mathrm{B}_{2}+\right)$ ), or NZ9000 $\left(\right.$ pNZGBAH) $\left.\left(B_{2}++\right)\right)$. Values are means, and standard deviations represented by vertical bars $(n 10) .{ }^{a, b}$ Mean values with unlike letters are significantly different $(P<0.05)$.

differences in bioavailable riboflavin as determined by HPLC, growth rates and EGRAC values.

No changes in haematological values or morphology of blood cells were observed in these trials (data not shown). This was an expected result since it was previously shown that riboflavin deficiency alone is not sufficient to change the haematological status of rats (Adelekan \& Thurnham, 1986). Also, there were no differences in relative spleen and kidney weights in all experimental groups (data not shown).

\section{Conclusions}

The objective of the present study was to evaluate the bioavailability of riboflavin from spontaneous and engineered riboflavin-overproducing $L$. lactis strains using a depletion-repletion rat bioassay. The bioavailability of the riboflavin produced by these strains is similar to that of pure riboflavin, taking into account growth rates and EGRAC values as indicators of the biological function of this vitamin. The addition of riboflavin-producing strains was shown to clearly improve the growth (Table 1) and riboflavin status of the depleted animals as shown by significant decreases to EGRAC values in rats supplemented with the engineered or native riboflavin-producing strains, where values reach similar levels as those seen in the non-depleted group (Fig. 3). Also, the riboflavin-producing strains were capable of curing hepatomegaly resulting from ariboflavinosis (Fig. 4).

The safety of use of novel strains must be addressed when they are to be proposed to be inserted into the food chain. In the present study no secondary effects were observed in animals fed the GM strains and haematological values, morphology of blood cells, and relative weight of organs of these animals were all similar to those obtained in the non-depleted groups. Only positive results were observed with the use of these strains, such as improved animal growth, EGRAC values and relative organ weight. The GM riboflavin-producing strain (L. lactis $\mathrm{B}_{2}++$ ) has been the object of a complete biosafety assessment in our laboratory and has been shown to be innocuous to the host (LeBlanc et al. 2005). Current legislation in most countries does not allow the addition of live GM strains in food products for human consumption, strongly limiting the use of the overproducing strain used in the present study. However, the use of spontaneous mutants, such as the riboflavin-producing strain, is generally accepted, greatly improving the possibilities that this strain could be included in novel products in a relatively short timeframe.

The present study has provided the first animal trial with food containing living bacteria that were selected or engineered to produce extracellular riboflavin in the fermented product. These results pave the way for analysing the effect of similar riboflavin-overproducing LAB in human trials. The development of fermented foods containing increased levels of riboflavin, produced in situ, which eliminates the need for vitamin fortification is currently underway. Since fermentation with $L$. lactis is a common practice in the dairy industry, the addition of the riboflavin-producing strain into products such as fermented milks, yoghurt, and cheeses in order to increase riboflavin concentrations is feasible and economically attractive since it would decrease the costs involved in current practices of vitamin fortification. The consumption of such products with increased levels of riboflavin on a regular basis could help prevent deficiencies of this important vitamin. Such products could decrease the costs incurred when mandatory fortification programmes are elaborated, such as those now in place in many industrialised countries.

The present study is one of many currently being addressed by the European NutraCells consortium (www.nutracells.com). The achievements of this multinational project should open the door to many applications in the development of both new food products with enhanced nutritional value and probiotic preparations with well-demonstrated in vivo activity.

\section{Acknowledgements}

The present study has been funded by the European Union project QLK1-CT-2000-01376 (www.nutracells.com), Consejo Nacional de Investigaciones Científicas y Técnicas (CONICET), Agencia de Promoción Científica y Tecnológica and CIUNT (Argentina). The authors would like to thank Analia Rossi and Silvia Burke for their help with the care of the animals and sampling. The authors would also like to thank Oscar Peinado Reviglione for his technical assistance in the HPLC analyses. All animal protocols were approved by the Animal Protection Committee of CERELA and followed the latest recommendations of the Federation of European Laboratory Animal Science Associations (FELASA). All experiments comply with the current laws of Argentina.

\section{References}

Adelekan DA \& Thurnham DI (1986) The influence of riboflavin deficiency on absorption and liver storage of iron in the growing rat. Br J Nutr 56, 171-179.

Bailey AL, Maisey S, Southon S, Wright AJ, Finglas PM \& Fulcher RA (1997) Relationships between micronutrient intake and biochemical indicators of nutrient adequacy in a free-living elderly UK population. Br J Nutr 77, 225-242.

Bates C (1993) Riboflavin. Int J Vitam Nutr Res 63, 274-277.

Benton D, Haller J \& Fordy J (1997) The vitamin status of young British adults. Int J Vitam Nutr Res 67, 34-40. 
Boisvert WA, Castaneda C, Mendoza I, Langeloh G, Solomons NW, Gershoff SN \& Russell RM (1993) Prevalence of riboflavin deficiency among Guatemalan elderly people and its relationship to milk intake. Am J Clin Nutr 58, 85-90.

Burgess C, O’Connell-Motherway M, Sybesma W, Hugenholtz J \& van Sinderen D (2004) Riboflavin production in Lactococcus lactis: potential for in situ production of vitamin-enriched foods. Appl Environ Microbiol 70, 5769-5777.

Butler BF \& Topham RW (1993) Comparison of changes in the uptake and mucosal processing of iron in riboflavin-deficient rats. Biochem Mol Biol Int 30, 53-61.

Capo-Chichi CD, Gueant JL, Feillet F, Namour F \& Vidailhet M (2000) Analysis of riboflavin and riboflavin cofactor levels in plasma by high-performance liquid chromatography. J Chromatogr B Biomed Sci Appl 739, 219-224.

Glatzle D, Körner WF, Christeller S \& Wiss O (1970) Method for the detection of a biochemical riboflavin deficiency. Stimulation of NADPH2-dependent glutathione reductase from human erythrocytes by FAD in vitro. Investigations on the vitamin $\mathrm{B}_{2}$ status in healthy people and geriatric patients. Int Z Vitaminforsch 40, 166-183.

Glatzle D, Weber F \& Wiss O (1968) Enzymatic test for the detection of a riboflavin deficiency. NADPH-dependent glutathione reductase of red blood cells and its activation by FAD in vitro. Experientia 24, 1122.

Greene HL, Specker BL, Smith R, Murrell J \& Swift L (1990) Plasma riboflavin concentrations in infants fed human milk versus formula: comparison with values in rats made riboflavin deficient and human cord blood. J Pediatr 117, 916-920.

Hustad S, McKinley MC, McNulty H, Schneede J, Strain JJ, Scott JM \& Ueland PM (2002) Riboflavin, flavin mononucleotide, and flavin adenine dinucleotide in human plasma and erythrocytes at baseline and after low-dose riboflavin supplementation. Clin Chem 48, 1571-1577.

Hustad S, Ueland PM, Vollset SE, Zhang Y, Bjørke-Monsen AL \& Schneede J (2000) Riboflavin as a determinant of plasma total homocysteine: effect modification by the methylenetetrahydrofolate reductase C677T polymorphism. Clin Chem 46, 1065-1071.

Lakshmi R, Lakshmi AV, Divan PV \& Bamji MS (1991) Effect of riboflavin or pyridoxine deficiency on inflammatory response. Indian J Biochem Biophys 28, 481-484.

LeBlanc JG, Burgess C, Sesma F, Savoy de Giori G \& van Sinderen D (2005) Ingestion of milk fermented by genetically modified
Lactococcus lactis improves the riboflavin status of deficient rats. J Dairy Sci (In the Press).

Madigan SM, Tracey F, McNulty H, Eaton-Evans J, Coulter J, McCartney H \& Strain JJ (1998) Riboflavin and vitamin B-6 intakes and status and biochemical response to riboflavin supplementation in free-living elderly people. Am J Clin Nutr 68, 389-395.

Institute for Laboratory Animal Research (1995) Nutrient Requirements of Laboratory Animals, 4th revised ed. Washington, DC: National Academy Press.

Ogunleye AJ \& Odutuga AA (1989) The effect of riboflavin deficiency on cerebrum and cerebellum of developing rat brain. J Nutr Sci Vitaminol (Tokyo) 35, 193-197.

Pangrekar J, Krishnaswamy K \& Jagadeesan V (1993) Effects of riboflavin deficiency and riboflavin administration on carcinogen-DNA binding. Food Chem Toxicol 31, 745-750.

Powers HJ (1987) A study of maternofetal iron transfer in the riboflavindeficient rat. J Nutr 117, 852-856.

Powers HJ, Weaver LT, Austin S \& Beresford JK (1993) A proposed intestinal mechanism for the effect of riboflavin deficiency on iron loss in the rat. Br J Nutr 69, 553-561.

Powers HJ, Weaver LT, Austin S, Wright AJ \& Fairweather-Tait SJ (1991) Riboflavin deficiency in the rat: effects on iron utilization and loss. Br J Nutr 65, 487-496.

Powers HJ, Wright AJ \& Fairweather-Tait SJ (1988) The effect of riboflavin deficiency in rats on the absorption and distribution of iron. Br J Nutr 59, 381-387.

Webster RP, Gawde MD \& Bhattacharya RK (1996) Modulation of carcinogen-induced DNA damage and repair enzyme activity by dietary riboflavin. Cancer Lett 98, 129-135.

Williams EA, Powers HJ \& Rumsey RD (1995) Morphological changes in the rat small intestine in response to riboflavin depletion. Br J Nutr 73, $141-146$.

Williams EA, Rumsey RD \& Powers HJ (1996) Cytokinetic and structural responses of the rat small intestine to riboflavin depletion. Br J Nutr $\mathbf{7 5}$, $315-324$.

Yates CA, Evans GS, Pearson T \& Powers HJ (2003) Absence of luminal riboflavin disturbs early postnatal development of the gastrointestinal tract. Dig Dis Sci 48, 1159-1164.

Yates CA, Evans GS \& Powers HJ (2001) Riboflavin deficiency: early effects on post-weaning development of the duodenum in rats. $\mathrm{Br} J$ Nutr 86, 593-599. 